\title{
PENGARUH LINGKUNGAN KERJA DAN KOMITMEN ORGANISASI TERHADAP KINERJA KARYAWAN PT. ANDALAN FINANCE DEPOK
}

Oleh:

\author{
Fikriah Saleh ${ }^{1}$ \\ Juni Mashita $^{2}$ \\ Vella Anggresta ${ }^{3}$ \\ 1), 2), 3) Fakultas Ilmu Pendidikan dan Pengetahuan Sosial \\ Program Studi Pendidikan Ekonomi \\ Universitas Indraprasta PGRI \\ Program Studi Pendidikan Ekonomi \\ Fakultas Ilmu Pendidikan dan Pengetahuan Sosial \\ Universitas Indraprasta PGRI \\ Email: \\ mail2me.fikriah@gmail.com
}

\begin{abstract}
ABSTRAK
Penelitian ini bertujuan untuk mengetahui pengaruh lingkungan kerja terhadap kinerja karyawan dan pengaruh komitmen organisasi terhadap kinerja karyawan. Penelitian dilakukan pada PT Andalan Finance Depok dengan melibatkan 102 orang karyawan sebagai sampel. Pendekatan penelitian adalah kuantitatif dengan metode deskriptif dan asosiatif. Hasil penelitian menunjukkan lingkungan kerja dan komitmen organisasi secara parsial berpengaruh positif dan signifikan terhadap kinerja karyawan. Hal ini ditunjukkan dengan $\mathbf{t}_{\text {hitung }}=16,410$ lebih besar dari padat tabel $=1,984$ pada derajat kebebasan dengan taraf nyata $\alpha=0,05$ maupun taraf nyata $\alpha=0,01\left(\mathbf{t}_{\text {tabel }}=2,626\right)$ hal ini berarti bahwa pengaruh antara lingkungan organisasi $\left(\mathrm{X}_{1}\right)$ dengan kinerja $(\mathrm{Y})$ adalah sangat signifikan dan $\mathbf{t}_{\text {hitung }}$ sebesar 8,134 lebih besar daripada $\mathbf{t}_{\text {tabel }}$ sebesar 1,984 pada derajat kebebasan dengan taraf nyata $\alpha=0,05$ maupun taraf nyata $\alpha=0,01\left(\mathbf{t}_{\text {tabel }}\right.$ sebesar 2,626$)$ hal ini berarti bahwa pengaruh antara komitmen organisasi $\left(\mathrm{X}_{2}\right)$ dengan kinerja $(\mathrm{Y})$ adalah sangat signifikan.
\end{abstract}

Kata Kunci: kinerja, komitmen organisasi, kuantitatif, lingkungan kerja 


\begin{abstract}
This study aims to determine the effect of the work environment on employee performance and the effect of organizational commitment on employee performance. The study was conducted at PT Andalan Finance Depok involving 102 employees as a sample. The research approach is quantitative with descriptive and associative methods. The results showed the work environment and organizational commitment partially had a positive and significant effect on employee performance. This is indicated by count $=16.410$ greater than payable $=$ 1.984 at the degree of freedom with a real level of $\alpha=0.05$ and a real level of $\alpha=$ $0.01\left(\mathrm{t}_{\text {table }}=2.626\right)$ this means that the influence between the organizational environment $\left(\mathrm{X}_{1}\right)$ with performance $(\mathrm{Y})$ is very significant and $\mathrm{t}_{\text {count }}$ as big as 8.134 is greater than $\mathrm{t}_{\text {table }}$ as big as 1.984 at the degree of freedom with a real level of $\alpha=0.05$ and a real level of $\alpha=0.01$ (table of 2.626) this means that the influence between organizational commitment $\left(\mathrm{X}_{2}\right)$ with performance $(\mathrm{Y})$ is very significant.
\end{abstract}

Keywords: performance, quantitative, organizational commitment, work environment,

\title{
A. PENDAHULUAN
}

Berhasil atau tidaknya sebuah perusahaanbiasanya akan ditandai oleh kemampuan perusahaan tersebut dalam mengelola sumber daya manusia yang dimiliki (Ukkas \& Latif, 2017). Jika suatu perusahaan ingin maju maka perlu adanya pengelolaan Sumberdaya Manusia yang tepat. Hal ini sangat penting untuk dilakukan karena jika perusahaan telah mengelola dengan tepat maka kinerja individu dari karyawan juga akan meningkat.

Kinerja karyawan merupakan faktor yang sangat penting dalam menunjang keberhasilan suatu perusahaan. Kinerja yang tinggi akan sangat menguntungkan baik bagi pengusaha maupun bagi karyawannya terutama untuk kesejahterannya. Kinerja juga mencerminkan etos kerja karyawan memiliki sikap mental yang baik. Dengan demikian, baik pengusaha maupun karyawan saling berupaya untuk meningkatkan kinerjanya dengan berbagai kebijakan yang secara efisien mampu meningkatkan kinerja karyawan. Kinerja karyawan diantaranya dipengaruhi oleh lingkungan kerja dan komitmen organisasi (Ghoniyah \& Masurip, 2011).

Mengingat peranan manusia dalam organisasi sangat penting maka perlu adanya komitemen setiap karyawan dan lingkungan kerja yang mendukung untuk bekerja sama yang baik dalam melaksanakan suatu tujuan perusahaan. Berapapun baiknya rencana yang dibuat oleh manajer, tanpa didukung oleh karyawan dalam melaksanakan pekerjaan, maka tujuan yang hendak dicapai tidak akan tercapai. Seorang karyawan mungkin menjalankan pekerjaan yang dibebankan kepadanya dengan baik mungkin pula tidak. Hal ini tambah lagi dengan perkembangan era teknologi yang mengakibatkan pegawai harus bisa beradaptasi dengan lingkungan baru.

Sejalan dengan perkembangan zaman, perubahan-perubahan dalam manajemen organisasi, tingkat kebutuhan hidup yang semakin meningkat dan 
berbagai persoalan lain menuntut adanya kemampuan dari para SDM (karyawan) untuk dapat menyesuaikan diri terhadap lingkungan fisik maupun lingkungan non fisik.Lingkungan kerja yang memuaskan bagi karyawannya dapat meningkatkan kinerja. Sebaliknya lingkungan kerja yang tidak memadai akan dapat menurunkan kinerja dan akhirnya menurunkan motivasi kerja karyawan (Potu, 2013).

Lingkungan kerja yang kondusif dan mendukung maka karyawan akan lebih semangat untuk hadir ke kantor, bekerja dengan sesuai target, lebih ceria dan cenderung terhindar dari stress. Lingkungan kerja yang positif juga menjadikan perusahaan akan lebih produktif dan efesien dalam melakukan proses produksi. Oleh sebab itu setiap pimpinan dalam perusahaan harus dapat semaksimal mungkin untuk menciptakan lingkungan kerja yang kondusif dan positif dalam mendukung kinerja karyawan.

Namun sebaliknya jika lingkungan kerja yang tidak nyaman dapat pula menjadi penyebab karyawan tidak betah dan akhirnya keluar dari perusahaan (Triyanto \& Santosa, 2009). Hal tersebut menjadi sangat wajar karena jika lingkungan tidak nyaman menjadikan karyawan tidak bersemangat untuk bekerja, tingkat ketidakhadiran tinggi dan kurang kerjasama dengan sesama karyawan lain karena tidak adanya dukungan. Malah berbagai studi menunjukkan aspek lingkungan dalam mempengaruhi sikap dan perilaku bawahan (Kartika, 2010). Hal tersebut dapat tambah diperparah saat masing-masing karyawan memiliki komitmen terhadap perusahaan yang rendah.

Komitmen organisasi berpengaruh positif dan signifikan terhadap prestasi kerja, semakin kuat komitmen organisasi karyawan maka semakin tinggi prestasi kerja karyawan (Dewanggana, Paramita, \& Andi, 2016). Prestasi karyawan mengacu kepada seberapa besar kinerja karyawan yang dihasilkan dalam suatu periode tertentu. Hal ini berarti bahwa karyawan yang memiliki komitmen terhadap perusahaan yang tinggi akan bekerja dengan maksimal sesuai dengan tugas, tanggungjawab dan beban kerja yang diberikan.

Komitmen organisasi menggambarkan hubungan diantara individu dengan organisasi, jika seorang karyawan memiliki komitmen organisasi yang tinggi, maka karyawan tersebut akanmempunyai kesetiaan, kepercayaan dan loyalitas pada organisasi dimana ia bekerja (Ukkas \& Latif, 2017).

Berdasarkan hasil pra penelitian, terdapat beberapa fenomena yang terjadi pada PT. Andalan Finance Depok yang diidentifikasikan oleh penulis sebagai penurunan kinerja. Kondisi tersebut terutama terlihat pada bagian pemasaran yang tidak mendapat nasabah atau tidak sesuai target. Namun kondisi yang sebaliknya terjadi ketika telah mencapai target, para karyawan terlihat sangat lepas, merdeka dan sangat bergembira.

Hal tersebut terjadi salah satunya disebabkan karena PT. Andalan Finance Depok memiliki jumlah beban kerja yang cukup berat. Hal ini penulis dapat data jumlah karyawan sebagai berikut: 
Tabel 1.

Target Kerja Karyawan di PT. Andalan Finance Depok Tahun 2015-2018

\begin{tabular}{ccc}
\hline Tahun & Rata-rata penjualan per bulan & Target Penjualan Karyawan \\
\hline 2015 & 25 & 75 \\
2016 & 46 & 80 \\
2017 & 63 & 88 \\
2018 & 76 & 90 \\
\hline & Sumber: Data Internal yang diolah peneliti
\end{tabular}

Berdasarkan data pada tabel di atas dapat diketahui jika target nasabah yang harus didapatkan oleh karyawan terlalu tinggi jika dibandingkan dengan kenyataan di lapangan. Ketika tahun 2015 rata-rata karyawan mendapatkan 25 konsumen perbulan sedangkan target penjualan sebesar 75. Pada tahun berikutnya adalah 46 sedangkan target penjualan adalah 80 dan kenaikan ini terjadi terus setiap tahunnya. Jumlah beban kerja karyawan yang tinggi dan semakin bertambah mengakibatkan setiap karyawan dituntut untuk selalu meningkatkan kinerjanya

Penurunan kinerja dapat dicirikan salah satunya dari segi makin lemahnya komitmen karyawan. Rendahnya komitmen tersebut salah satu terlihat pada meningkatnya absensi dan keterlambatan. Peneliti melihat dalam 6 bulan terakhir pada tahun 2018 terjadi peningkatan jumlah rata-rata keterlambatan dan absensi ketidakhadiran karyawan di PT. Andalan Finance Depok seperti yang tertuang pada tabel di bawah ini :

Tabel 2.

Daftar Kehadiran Karyawan di PT. Andalan Finance Depok

\begin{tabular}{ccccc}
\hline No & Bulan & Jumlah Karyawan & Keterlambatan & Persentase (\%) \\
\hline 1 & Juli & 49 & 17 & $34,69 \%$ \\
2 & Agustus & 49 & 18 & $36,73 \%$ \\
3 & September & 49 & 18 & $36,73 \%$ \\
4 & Oktober & 51 & 23 & $45,1 \%$ \\
5 & November & 52 & 22 & $42,31 \%$ \\
6 & Desember & 55 & 29 & $52,73 \%$ \\
\hline \multicolumn{3}{c}{ Sumber: Data Internal yang diolah peneliti }
\end{tabular}

Berdasarkan tabel di atas diketahui jika tingkat keterlambatan karyawan tergolong cukup tinggi jika dibandingkan dengan jumlah karyawan di PT. Andalan Finance Depok. Pada bulan Juli terjadi 17 orang karyawan yang terlambat atau sekitar 34,69\% dari total karyawan. Selain tinggi, hampir setiap tahunnya selalu terjadi peningkatan. Hal ini tentu saja sangat berpengaruh terhadap kinerja karyawan. Jika komitmen dan lingkungan kerja di PT Andalan Finance Depok tidak segera ditanggulangi maka di prediksi akan terus terjadi penurunan kinerja karyawan.

PT. Andalan Finance Depok lebih mengutamakan pada penciptaan kondisi kerja yang nyaman dan aman bagi para pegawai dalam upaya peningkatan kinerja karyawan. PT. Andalan Finance Depok juga memberikan fasilitas-fasilitas yang menunjang dalam meningkatkan kinerja kepada seluruh karyawannya. Fasilitasfasilitas tersebut meliputi pakaian kerja, rekreasi, tunjangan hari raya, ruang 
pengobatan, asuransi, bonus, upah lembur dan sebagainya. Semua itu diberikan oleh perusahaan agar seluruh karyawan yang bekerja di dalamnya benar-benar terjamin sekaligus dapat menciptakan suatu motivasi yang baik dan mengurangi tingkat stres pegawai guna mencapai tingkat kinerja. Berdasarkan hal tersebut maka peneliti tertarik untuk melakukan penelitian Pengaruh Lingkungan Kerja Dan Komitmen Organisasi Terhadap Kinerja Karyawan PT. Andalan Finance Depok.

\section{B. KAJIAN PUSTAKA}

\section{Kinerja Karyawan}

Kinerja pada umumnya diartikan sebagai kinerja, hasil kerja atau prestasi kerja. Kinerjamemiliki makna yang cukup luas, bukan hanya menyatakan sebagai hasil kerja, tetapi juga bagaimana proses kerja berlangsung (Nur, 2013). Pendapat lain pengertian kinerja karyawan dapat diartikan sebagai otuput atau hasil kerja karyawan sesuai dengan tugas dan tanggung jawabnya untuk mencapai tujuan organisasi (Trang, 2013). Menurut Payamandalam (Ariyanty, 2014) kinerja adalah tingkat pencapaian hasil atau pelaksanaan tugas tertentu.

Faktor-faktor yang mempengaruhi kinerja menurut Mathis dan Jackson dalam (Lina, 2014) adalah sebagai berikut: Kemampuan, motivasi, dukungan yang diterima, keberadaan pekerjaan yang mereka lakukan dan hubungan mereka dengan organisasi. Indikator dari kinerja adalah kuantitas, kualitas, efisiensi, kemampuan, ketepatan, pengetahuan dan kreativitas (Taurisa, 2014). Pendapat lain mengenai indikator kinerja di sampaikan oleh Trang, yaitu quality, quantity, timeless, cost effectiveness, need for supervision dan interpersonal impact (Trang, 2013). Berdasarkan pendapat para pakar tersebut dapat disimpulkan kinerja adalah tingkat pencapaian hasil kerja yang dihasilkan oleh karyawan dengan indikator kualitas kerja, kuantitas kerja, dan pemanfaatan waktu.

\section{Lingkungan Kerja}

Lingkungan kerja yaitu segala sesuatu yang ada di sekitar pekerja, yang dapat mempengaruhi dirinya dalam menjalankan tugas(Dhermawan, Sudibya, \& Utama, 2012). Lingkungan kerja di perusahaan juga mempengaruhi kinerja yang dilaksanakan oleh karyawan(Munparidi, 2012). Pendapat lain menyatakan Lingkungan kerja merupakan segala sesuatu yang ada di sekitar karyawan pada saat bekerja, baik yang berbentuk fisik ataupun non fisik, langsung atau tidak langsung, yang dapat mempengaruhi dirinya dan pekerjaanya saat bekerja(Potu, 2013). Menurut Widodo Lingkungan kerja menunjuk pada hal-hal yang berada disekeliling dan melingkupi kerja karyawan di kantor(Widodo, 2010).

Lingkungan kerja terbagi atas 2 , yaitu lingkungan fisik dan non fisik (Munparidi, 2012). Lingkungan kerja fisik merupakan fasilitas (gedung, kursi, meja) yang terlihat dan dapat disentuh oleh karyawan selama berada di dalam kantor. Lingkungan kerja nonfisik yang meliputi keramahan sikap para karyawan, sikap saling menghargai diwaktu berbeda pendapat. Indikator lingkungan kerja meliputi hubungan karyawan, suasana kerja, fasilitas kerja dan keamanan (Permanasari, 2013). Pendapat lain mengenai indikator lingkungan kerja hadir 
menurut suhu udara tempat kerja, tata ruang, sirkulasi udara di tempat kerja, pencahayaan, hubungan antar karyawan dan hubungan karyawan dengan pimpinan (Suwondo \& Sutanto, 2015).

Berdasarkan pendapat para ahli tersebut dapat disimpulkan lingkungan kerja adalah segala sesuatu yang ada pada tempat kerja, baik dalam bentuk fisik dan non fisik dengan indikator hubungan karyawan, suasana kerja, fasilitas kerja, suhu dan sirkulasi udara di tempat kerja.

\section{Komitmen Organisasi}

Komitmen organisasi merupakan keterlibatan karyawan dalam loyalitasnya pada organisasi, kesediaan untuk mengarahkan usaha, tujuan dan nilai sejalan dengan organisasi dan keinginan untuk mempertahankan keanggotaannya dalam organisasi (Ghoniyah \& Masurip, 2011). Pendapat lain mengatakan komitmen merupakan kecenderungan individu untuk bertahan dalam organisasi karena adanya persepsi bahwa dirinya akan mengalami kerugian bila meninggalkan organisasi tersebut (Fitriastuti, 2013).

Menurut Mowday, Porter dan Steers dalam (Kurniawan, 2015) menyebutkan bahwakomitmen organisasi adalah sifat hubungan seorang individu dengan organisasi dengan memperlihatkan ciri-ciri sebagai berikut: (1) Menerima nilai-nilai dan tujuan organisasi. (2) Mempunyai keinginan berbuat untuk organisasinya. (3) Mempunyai keinginan yang kuat untuk tetap bersama dengan organisasinya. Allen dan Mayer dalam (Darmawati, Hidayati, \& S, 2013) mengemukakan tiga dimensi komitment organisasi, yaitu komitmen afektif, komitmen berkelanjutan dan komitmen normatif. Pendapat lain indikator komitmen organisasi meliputi taat pada peraturan, Tanggung jawab pada perusahaan, Kemauan untuk bekerja sama, Rasa memiliki dan Hubungan antar pribadi (Kiswari, Fathoni, \& Minarsih, 2016).

Berdasarkan seluruh pendapat para ahli tersebut dapat disimpulkan komitmen organisasi adalah kecenderungan individu untuk bertahan di dalam organisasi dan kesediaan untuk mengarahkan usaha, tujuan dan nilai sejalan dengan organisasi dengan indikator komitmen afektif, komitmen berkelanjutan dan komitmen normatif.

\section{METODE PENELITIAN}

Penelitian ini dilakukan pada PT. Andalan Finance Depokdari Bulan Desember 2018 sampai dengan Maret 2019. Pendekatan penelitian adalah kuantitatif dengan metode deskriptif dan asosiatif. Metode deskriptif diartikan is one form of research that aims to describe the event or the occurrence of variables in the study (Prasetyono, Abdillah, Widiarto, \& Sriyono, 2018). Sedangkan asosiatif diartikan sebagaiassociative research is to predict how the influence of independent variables to the dependent variable then analyzed by (Prasetyono, Abdillah, \& Fitria, 2018). Adapun modeldari penelitian adalah sebagai berikut: 


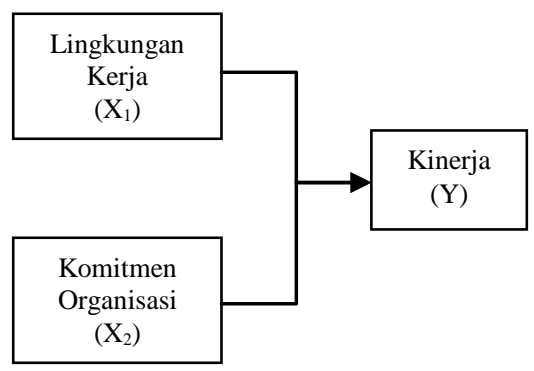

\section{Gambar 1. Model Penelitian}

Populasi dalam penelitian ini adalah seluruh karyawan yang ada di PT. Andalan Finance Depok berjumlah 205 orang karyawan.Teknik pengambilan sampel dilakukan dengan menggunakan metode simple random sampling. Jumlah sampel dihitung menggunakan rumus Slovin (Prasetyono, Abdillah, \& Fitria, 2018) dengan tingkat kesalahan 7\% didapatkan hasil sebagai berikut:

$$
\begin{gathered}
n=\frac{N}{1+N \cdot e^{2}} \\
n=\frac{205}{1+205 \cdot(0,07)^{2}}=102,27 \text { dibulatkan menjadi } 102
\end{gathered}
$$

Penelitian dilakukan dengan langsung di lapangan dengan menyebar kuesioner. Menurut Fitria, Abdillah, Prasetyono, \& Cahyo (2019) disebut penelitian lapangan karena because this research is done by directly relating to the object of research. Pengumpulan data menggunakan kuesioner yang disusun berdasarkan indicator setiap variabel.

\section{HASIL DAN PEMBAHASAN}

\section{Pengaruh lingkungan terhadap kinerja}

Setelah dilakukan perhitungan dan analisis terhadap data kinerja karyawan (Y) dengan lingkungan organisasi $\left(\mathrm{X}_{1}\right)$ didapat persamaan regresi: $Y=$ $-36,874+0,866 X_{1}$. Untuk melihat apakah persaman regresi tersebut linear atau tidak dilakukan Uji signifikansi regresi dan uji linearitas regresi tersebut dengan menggunkan tabel Analisis Varian (ANAVA) yang dapat dilihat pada tabel berikut ini: 
Tabel 6.

ANAVA untuk pengujian Signifikansi dan Linearitas Regresi $Y$ atas $X_{1}$ $\left(Y=-36,874+0,866 X_{1}\right)$

\begin{tabular}{lrrrcrcc}
\hline \multicolumn{1}{c}{$\begin{array}{c}\text { Sumber } \\
\text { Variasi }\end{array}$} & Dk & JK & RJK & $\mathbf{F}_{\text {hitung }}$ & $\begin{array}{c}\mathbf{F}_{\text {tab }} \\
(\boldsymbol{\alpha}=\mathbf{0 , 0 5})\end{array}$ & $\begin{array}{c}\mathbf{F}_{\text {tab }} \\
(\boldsymbol{\alpha}=\mathbf{0 , 0 1})\end{array}$ \\
\hline Total & 102 & $812,319.00$ & & & & & \\
Koefisien (a) & 1 & $801,014.91$ & & & & & \\
Regresi (b/a) & 1 & $8,243.06$ & $8,243.06$ & 269.290 & $* *$ & 3.936 & 6.895 \\
Sisa & 100 & $3,061.03$ & 30.61 & & & & \\
Tuna Cocok & 45 & 107.99 & 2.40 & 0.045 & ns & 1.593 & \\
Galat & 55 & $2,953.04$ & 53.69 & & & & \\
\hline
\end{tabular}

Keterangan:

dk = derajat kebebasan; Jk = Jumlah Kuadrat; RJK = Rata-rata Jumlah Kuadrat

$* *$ = Sangat signifikan; ns $\quad=$ Non signifikan

Hasil ANAVA terhadap model ini seperti pada tabel diatas, diperoleh bahwa $F_{\text {hitung }}$ sebesar 269,290 $>F_{\text {tabel }(\alpha=0,05)}$ sebesar 3,936. Dengan demikian dapat dikemukakan bahwa model pengujian regresi tersebut adalah sangat siginifikan. Selanjutnya hasil ANAVA tersebut memperlihatkan bahwa nilai $\mathrm{F}_{\text {hitung }}$ Tuna Cocok sebesar $0,045<\mathrm{F}_{\text {tabel }}(\alpha=0,05) 1,593$. Hal ini menunjukkan bahwa garis persamaan regresi $\mathrm{Y}=-36,874+0,866 \mathrm{X}_{1}$ adalah linear. Dengan demikian dapat dikatakan bahwa pengaruh lingkungan organisasi $\left(\mathrm{X}_{1}\right)$ terhadap kinerja karyawan (Y) adalah sangat signifikan dan linear.Model regresi tersebut mengandung arti bahwa apabila lingkungan organisasiditingkatkan satu point, maka kinerja karyawan cenderung meningkat sebesar 0,866 poin pada konstanta $-36,874$.

Selanjutnya dilakukan pengujian koefisien korelasi dengan Pearson Product Moment terhadap hubungan antara lingkungan organisasi dengan kinerja karyawan(Y). Dari hasil perhitungan diperoleh koefisien korelasi sebesarr $_{\mathrm{y} 1}=$ 0,854 , kemudian terhadap nilai korelasi tersebut dilakukan pengujian signifikansi dengan menggunakan uji-t (statistic $t$-student)dan hasil perhitungan dapat dilihat pada tabel dibawah ini:

Tabel 7.

Uji Signifikansi Korelasi $\mathrm{X}_{1}$ dengan $\mathrm{Y}$

\begin{tabular}{cccc}
\hline Koefisien korelasi & $\mathbf{T}_{\text {hitung }}$ & $\mathrm{T}_{\text {tabel }}(0,05)$ & $\mathrm{T}_{\text {tabel }}(0,01)$ \\
\hline 0,854 & $16,410^{* *}$ & 1,984 & 2,626 \\
\hline = sangat signifikan & & &
\end{tabular}

Dilihat dari tabel diatas, bahwa $t_{\text {hitung }}=16,410$ lebih besar dari pada $t_{\text {tabel }}=$ 1,984 pada derajat kebebasan dengan taraf nyata $\alpha=0,05$ maupun taraf nyata $\alpha=$ $0,01\left(\mathrm{t}_{\text {tabel }}=2,626\right)$ hal ini berarti bahwa pengaruh antara lingkungan organisasi $\left(\mathrm{X}_{1}\right)$ dengan kinerja $(\mathrm{Y})$ adalah sangat signifikan. Hasil ini relevan dengan hasil penelitian (Suwondo \& Sutanto, 2015) dan penelitian dari (Sidanti, 2015) yang salah satu kesimpulannya menyatakan penelitian lingkungan kerja berpengaruh terhadap kinerja karyawan.

\section{Pengaruh komitmen terhadap kinerja}


Setelah dilakukan perhitungan dan analisis terhadap data kinerja karyawan (Y) dengan komitmen organisasi $\left(\mathrm{X}_{2}\right)$ didapat persamaan regresi: $\mathrm{Y}=30,331+$ $0,516 \mathrm{X}_{2}$. Untuk melihat apakah persaman regresi tersebut linear atau tidak dilakukan Uji signifikansi regresi dan uji linearitas regresi tersebut dengan menggunkan tabel Analisis Varian (ANAVA) yang dapat dilihat pada tabel berikut ini :

Tabel 8.

ANAVA untuk pengujian Signifikansi dan Linearitas Regresi $Y$ atas $X_{2}$ $\left(\mathbf{Y}=\mathbf{3 0 , 3 3 1}+\mathbf{0 , 5 1 6} \mathrm{X}_{2}\right)$

\begin{tabular}{lcrrrrrr}
\hline $\begin{array}{c}\text { Sumber } \\
\text { Variasi }\end{array}$ & dk & JK & RJK & $\mathbf{F}_{\text {hitung }}$ & $\begin{array}{c}\mathbf{F}_{\text {tab }} \\
(\boldsymbol{\alpha}=\mathbf{0 , 0 5})\end{array}$ & $\begin{array}{c}\mathbf{F}_{\text {tab }} \\
(\boldsymbol{\alpha}=\mathbf{0 , 0 1})\end{array}$ \\
\hline Total & 102 & $812,319.00$ & & & & & \\
Koefisien (a) & 1 & $801,014.91$ & & & & & \\
Regresi (b/a) & 1 & $4,500.70$ & $4,500.70$ & 66.154 & $* *$ & 3.936 & 6.895 \\
Sisa & 100 & $6,803.38$ & 68.03 & & & & \\
Tuna Cocok & 45 & $1,053.68$ & 23.42 & 0.224 & ns & 1.593 & \\
Galat & 55 & $5,749.70$ & 104.54 & & & &
\end{tabular}

Keterangan:

$\mathrm{dk}=$ derajat kebebasan; Jk = Jumlah Kuadrat; RJK = Rata-rata Jumlah Kuadrat

** = Sangat signifikan; ns = Non signifikan

Hasil ANAVA terhadap model ini seperti pada tabel diatas, diperoleh bahwa $F_{\text {hitung }}$ regresi 66,154> $F_{\text {tabel }}(\alpha=0,05)$ 3,936. Dengan demikian dapat dikemukakan bahwa model pengujian regresi tersebut adalah sangat siginifikan. Selanjutnya hasil ANAVA tersebut memperlihatkan bahwa nilai $F_{\text {hitung }}$ Tuna Cocok 0,224 < $\mathrm{F}_{\text {tabel }}(\alpha=0,05)$ 1,593. Hal ini menunjukkan bahwa garis persamaan regresi $\mathrm{Y}=30,331+0,516 \mathrm{X}_{2}$ adalah linear. Dengan demikian dapat dikatakan bahwa pengaruh komitmen $\left(\mathrm{X}_{2}\right)$ terhadap kinerja karyawan $(\mathrm{Y})$ adalah sangat signifikan dan linear. Model regresi tersebut mengandung arti bahwa apabila komitmenditingkatkan satu point, maka kinerja karyawan cenderung meningkat sebesar 0,516 poin pada konstanta 30,331 .

Selanjutnya dilakukan pengujian koefisien korelasi dengan Pearson Product Moment terhadap hubungan antara komitmendengan kinerja karyawan (Y). Dari hasil perhitungan diperoleh koefisien korelasi sebesar $\mathrm{r}_{\mathrm{y} 2}$ sebesar 0,631 , kemudian terhadap nilai korelasi tersebut dilakukan pengujian signifikansi dengan menggunakan uji-t (statistic t-student) dan hasil perhitungan dapat dilihat pada tabel dibawah ini:

Tabel 9.

Uji Signifikansi Korelasi $\mathrm{X}_{2}$ dengan $\mathrm{Y}$

\begin{tabular}{cccc}
\hline Koefisien korelasi & $\mathbf{T}_{\text {hitung }}$ & $\mathbf{t}_{\text {tabel }}(0,05)$ & $\mathbf{t}_{\text {tabel }}(0,01)$ \\
\hline 0,631 & $8,134 * *$ & 1,984 & 2,626 \\
\hline$* *$ = sangat signifikan & & &
\end{tabular}

Dilihat dari tabel diatas, bahwa $t_{\text {hitung }}$ sebesar 8,134 lebih besar daripada $t_{\text {tabel }}$ sebesar 1,984 pada derajat kebebasan dengan taraf nyata $\alpha=0,05$ maupun taraf 
nyata $\alpha=0,01\left(\mathrm{t}_{\text {tabel }}\right.$ sebesar 2,626$)$ hal ini berarti bahwa pengaruh antara komitmen organisasi $\left(\mathrm{X}_{2}\right)$ dengan kinerja $(\mathrm{Y})$ adalah sangat signifikan. Hasil tersebut didukung oleh penelitian yang dilakukan oleh (Taurisa, 2014) dan (Fitriastuti, 2013) yang salah satu kesimpulannya menuliskan komitmen organisasional memiliki pengaruh positif signifikan terhadap kinerja karyawan.

\section{E. SIMPULAN}

Berdasarkan pengujian hipotesis yang telah dilakukan maka dapat disimpulkan lingkungan kerja dan komitmen organisasi secara parsial berpengaruh positif dan signifikan terhadap kinerja karyawan. Hal ini diharapkan menjadi perhatian bagi manajemen PT Andalan Finance Depok untuk selalu menciptakan lingkungan kerja yang kondusif dan mendukung karyawan bekerja serta meningkatkan komitmen organisasi karyawan. 


\section{DAFTAR PUSTAKA}

Ariyanty, N. (2014). Pengaruh Budaya Organisasi Terhadap Kinerja Pegawai. Jurnal Manajemen \& Bisnis, 14(02), 144-150.

Darmawati, A., Hidayati, Li. N., \& S, D. H. (2013). Pengaruh Kepuasan Kerja Dan Komitmen Organisasi Terhadap Organizational Citizenship Behavior. Jurnal Economia, 9(1), 10-17.

Dewanggana, B. D., Paramita, P. D., \& Andi, T. H. (2016). Organisasi Terhadap Organizational Citizenship Behavior ( OCB ) Yang Berdampak Pada Prestasi Kerja Karyawan. Journal of Management, 2(2), 1-10.

Dhermawan, A. A. N. B., Sudibya, I. G. A., \& Utama, I. W. M. (2012). Pengaruh Motivasi, Lingkungan Kerja, Kompetensi, Dan Kompensasi Terhadap Kepuasan Kerja Dan Kinerja Pegawai Di Lingkungan Kantor Dinas Pekerjaan Umum Provinsi Bali. Jurnal Manajemen, Strategi Bisnis, Dan Kewirausahaan, 6(2), 173-184.

Fitria, D., Abdillah, A., Prasetyono, H., \& Cahyo, I. D. (2019). The Difference of Enterprises Taxpayers Compliance after Tax Amnesty. Journal of Economics and Policy, 12(1), 86-99. https://doi.org/https://doi.org/10.15294/jejak.v12i1.18826

Fitriastuti, T. (2013). Pengaruh Kecerdasan Emosional, Komitmen Organisasional Dan Organizational Citizenship Behavior Terhadap Kinerja Karyawan. Jurnal Dinamika Manajemen, 4(2), 103-114. Retrieved from http://journal.unnes.ac.id/nju/index.php/jdm

Ghoniyah, N., \& Masurip, M. (2011). Peningkatan Kinerja Karyawan Melalui Kepemimpinan, Lingkungan Kerja Dan Komitmen. Jurnal Dinamika Manajemen, 2(2), 118-129. Retrieved from http://journal.unnes.ac.id/nju/index.php/jdm

Kartika, A. (2010). Pengaruh Komitmen Organisasi dan Ketidakpastian Lingkungan dalam Hubungan Antara Partispasi Anggaran dengan Senjangan Anggaran (Studi Empirik Pada Rumah Sakit Swasta di Kota Semarang) The. Jurnal Kajian Akuntansi, 2(1), 39-60.

Kiswari, Y., Fathoni, A., \& Minarsih, M. M. (2016). Pengaruh Kepuasan Kerja, Persepsi Pegawai Dan Komitmen Organisasi Pegawai Tehadap Organizational Citizenship Behavior (Studi Kasus Pada PT. Berkah Illahi Di Kota Semarang). Journal of Management, 2(2), 545-564.

Kurniawan, A. (2015). Pengaruh Komitmen Organisasi terhadap Organizational Citizenship Behavior (OCB) PT X Bandung. Jurnal Manajemen, 15(1), 95118.

Lina, D. (2014). Analisis Pengaruh Kepemimpinan Dan Budaya Organisasi Terhadap Kinerja Pegawai Dengan Sistem Reward Sebagai Variabel Moderating. Jurnal Riset Akuntansi Dan Bisnis, 14(1), 77-97. 
Munparidi, M. (2012). Pengaruh Kepemimpinan, Motivasi, Pelatihan, Dan Lingkungan Kerja Terhadap Kinerja Karyawan Pada Perusahaan Daerah Air Minum Tirta Musi Kota Palembang. Jurnal Orasi Bisnis, VII, 47-54. Retrieved from http://jurnal.polsri.ac.id/index.php/admniaga/article/view/153

Nur, S. (2013). Konflik, stres kerja dan kepuasan kerja pengaruhnya terhadap kinerja pegawai pada Universitas Khairun Ternate. Jurnal EMBA, 1(3), 739-749.

Permanasari, R. (2013). Pengaruh Motivasi Dan Lingkungan Kerja Terhadap Kinerja PT. Augrah Raharjo Semarang. Jurnal Management Analysis Journal, 2(2), 1-9.

Potu, A. (2013). Kepemimpinan, Motivasi, dan Lingkungan Kerja Pengarugnya Terhadap Kinerja Karyawan Pada Kanwil Ditjen Kekayaan Negara Suluttenggodan Maluku Uutara di Manado. Jurnal Emba, 1(4), 1208-1218. Retrieved from http://pasca.unhas.ac.id/jurnal/files/4869b786de43116c182e7dfbed1fd5fb.p df

Prasetyono, H., Abdillah, A., \& Fitria, D. (2018). Academic Supervision toward Teacher' s Performance through Motivation as an Intervening Variable. Journal of Education and Learning (EduLearn), 12(2), 188-197. https://doi.org/10.11591/edulearn.v12i2.7324

Prasetyono, H., Abdillah, A., Widiarto, T., \& Sriyono, H. (2018). Character-Based Economic Learning Implementation And Teacher's Reinforcement On Student's Affective Competence In Minimizing Hoax. Jurnal Cakrawala Pendidikan, 37(3), 426-435.

Sidanti, H. (2015). Pengaruh Lingkungan Kerja, Disiplin Kerja Dan Motivasi Kerja Terhadap Kinerja Pegawai Negeri Sipil Di Sekretariat DPRD Kabupaten Madiun. Jurnal JIBEKA, 9(1), 44-53.

Suwondo, D. I., \& Sutanto, E. M. (2015). Hubungan Lingkungan Kerja, Disiplin Kerja, Dan Kinerja Karyawan. Jurnal Manajemen Dan Kewirausahaan, 17(2), 135-144. https://doi.org/10.9744/jmk.17.2.135

Taurisa, C. M. (2014). Analisis Pengaruh Budaya Organisasi Dan Kepuasan Kerja Terhadap Komitmen Organisasional Dalam Meningkatkan Kinerja Karyawan (Studi pada PT. Sido Muncul Kaligawe Semarang). Jurnal Economia, 7(2), 1-16.

Trang, D. S. (2013). Gaya Kepemimpinan Dan Budaya Organisasi Pengaruhnya Terhadap Kinerja Karyawan (Studi pada Perwakilan BPKP Provinsi Sulawesi Utara). Jurnal EMBA, 1(3), 208-216.

Triyanto, A., \& Santosa, T. E. C. (2009). Organizational Citizenship Behavior ( OCB ) Dan Pengaruhnya Terhadap Keinginan Keluar dan Kepuasan Kerja Karyawan. Jurnal Manajemen, 7(4), 1-13. 
Ukkas, I., \& Latif, D. (2017). Pengaruh Iklim Organisasi Dan Loyalitas Kerja Terhadap Organizational Citizenship Behavior. Jurnal Equilibrium, 6(1), 19-28.

Widodo, T. (2010). Pengaruh Lingkungan Kerja, Budaya Organisasi, Kepemimpinan Terhadap Kinerja (Studi pada Pegawai Kecamatan Sidorejo Kota Salatiga). Jurnal Among Makarti, 3(5), 14-35. 